\title{
LA ODISEA DEL SIGLO XXI: EL RESCATE DE LA FAMILIA
}

Héctor Lerma Jasso

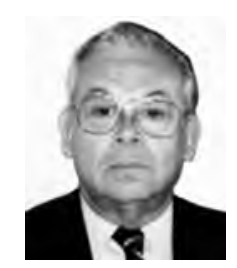

Licenciado en Pedagogía, Universidad Panamericana, Sede México.

Licenciado en Filosofía, Universidad Panamericana, Sede México.

Doctor en Filosofía, Universidad de Navarra.

Autor, entre otros, de: «¿Qué tipo de alumno soy?»y «Paternidad: excelencia o fracaso». Colaborador habitual de la revista Istmo. Ha impartido, en el país y en el extranjero, una gran cantidad de cursos a empresarios, padres de familia y maestros.

Correo electrónico: [hlerma@mx.up.mx].

\section{RESUMEN}

¿Pueden relacionarse la familia y la Odisea, obra épica atribuida a Homero? Sí, si hablamos de la familia como valor y fuente de valores en la mentalidad y conducta del héroe; como lugar privilegiado de intimidad e identidad, de aceptación y realización personal; garantía de una sociedad más justa, más libre y más segura.

A fin de cuentas, el sendero de la familia recorre una travesía que nos vincula entrañablemente con la palabra odisea: una aventura larga y peligrosa, saturada de retos a vencer y metas a conquistar; es decir, un proyecto formativo que ha de llevarse, por su propia naturaleza, no sólo a término, sino a buen término. 
Palabras clave: familia; odisea; pedagogía del liderazgo; héroe; identidad; líder con valores; rescate de la familia.

\section{ABSTRACT}

Can Homers epic masterpiece, the Odyssey, and the family be related? It can if we talk about the family in terms of values and the source of values in the heroes conduct and mentality; as a privileged place of intimacy and identity, of acceptance and self-development; guaranty of a much fair society, more free and secure.

Finally, the family's path goes through a journey that connects us deeply with the word odyssey: a long and dangerous adventure, saturated of challenges to be surpassed and goals to achieve; in other words, a formative project that should be taken, by it's own nature, not only to an end, but to a good end.

Key words: family: odyssey; pedagogy of leadership; hero; identity; leadership with values; family rescue.

Cuando defendemos la familia no queremos decir que siempre sea una familia tranquila y en paz; cuando mantenemos la tesis del matrimonio no queremos decir que es siempre un matrimonio feliz. Lo que queremos decir es que es el teatro del drama espiritual, el lugar donde las cosas ocurren de verdad, sobre todo las que son importantes

(Chesterton) ${ }^{12}$.

${ }_{12}$ G.K. Chesterton, El amor o la fuerza del sino, p. 47. 


\section{«DICE UNA ANTIGUA LEYENDA QUE ME ACABO DE INVENTAR...»}

Así comienza Chesterton ${ }^{13}$ uno de sus amenos relatos. Pero no se trata de inventar aquí otra antigua leyenda sino, simplemente, de señalar ciertas conexiones útiles entre la Odisea -ésa sí: antigua leyenda épica atribuida al legendario Homero ${ }^{14}$ - y el llamado liderazgo con valores.

Quizá surja cierta extrañeza: ¿es que puede haber alguna relación aprovechable entre ambos discursos?

A mi modo de ver, sí: la hay; tan estrecha y pragmática que rebasa la mera abstracción académica. Porque la Odisea - obra de valor universal escrita hace casi tres mil años- aborda, junto a narraciones fabulosas, temas de profundo y perenne interés humano. Por algo ha ejercido gran influencia entre filósofos, artistas y educadores de todos los tiempos y latitudes ${ }^{15}$; y sigue manteniendo, en nuestros días, una vigorosa presencia en todas las manifestaciones culturales.

Sus páginas, saturadas de férreos caracteres, aventuras insólitas, sorprendentes simbologías y juiciosas reflexiones, permiten lecturas y claves

${ }^{13}$ La asociación entre la Odisea y el líder con valores es sugerida por Gilbert K. Chesterton, considerado: un escritor para todos los tiempos y un clásico de la literatura británica, y probablemente el más citado de nuestro siglo $[\mathrm{XX}]$ —-según señala Luis Ignacio Seco-. En efecto: no hubo género literario que el autor de El amor o la fuerza del sino no abordara con originalidad y maestría... Ver el mundo con la extraordinaria frescura de sus ojos, será siempre una terapia de comprobada eficacia. Quizá por ello la afirmación de Sir Arthur Bryant de que "La influencia de Chesterton será más grande entre las generaciones aún no nacidas que entre sus contemporáneos», va camino de convertirse en una profecía. Chesterton - resume Alfonso Reyes-entendió la vida.

Después de leerlo de cabo a rabo —concluye Borges-es imposible encontrar en sus obras una sola página que no ofrezca una felicidad. Y Luis Ignacio Seco añade: No conozco a ningún lector de Chesterton que no trate de pensar por su cuenta, que no tenga sentido del humor y que no ponga a la libertad - la suya y la de los demás - en la cumbre de sus aspiraciones. Familia, alegría, inteligencia, libertad son, según Chesterton, temas inseparables.

${ }^{14}$ Homero (s. VIII a.C.) fue un poeta griego, autor de la Ilíada y la Odisea, considerado el primer gran educador de la Hélade. Al parecer vivió en Asia Menor. La leyenda lo representa como un viejo ciego, vagando de ciudad en ciudad, recitando sus versos.

15 Sócrates, Sófocles, Píndaro, Dante, Shakespeare, Racine, Göethe, Joyce, Tennyson, Vasconcelos..., serían sólo unos pocos ejemplos. 
interpretativas muy diversas. Desde la óptica de una pedagogía del liderazgo - de un liderazgo con valores - podemos inferir un tema de franca raigambre axiológica: la influencia de la familia, como valor y fuente de valores, en la mentalidad y conducta del héroe. O dicho de otro modo: la importancia de la familia en la formación de un líder con valores.

No es, pues, la Odisea, sólo la epopeya de una gran conquista de tierras, mares, oro, gloria... y tratamientos VIP, a fuerza de audacia, paciencia $e$ inteligencia. Aunque la palabra odisea eso significa: aventura larga y peligrosa, saturada de retos a vencer y metas a conquistar. El poema homérico es, sobre todo, el proyecto formativo de un héroe tan admirado, tan clásico y tan genial como Ulises (Odysseus), rey de Ítaca, inventor del subterfugio del famoso caballo que decidió el triunfo griego en la Guerra de Troya. Líder que no deseaba otra cosa que volver a su patria, a su mujer, a su hijo, a su hogar ${ }^{16}$. Ni las tretas de los hombres, ni la furia de los dioses, lograron impedir al héroe recuperar a su familia.

\section{ODISEA: UNA PEDAGOGÍA DEL LIDERAZGO}

La Ilíada y la Odisea atestiguan que, muy pronto, la Grecia primitiva comenzó a tomar clara conciencia acerca de la naturaleza, extensión y fundamentos de la educación (Paideia). Sobre todo de la educación del héroe, del dirigente, del líder: del hombre adulto, capaz no sólo de cuidar de sí mismo y de responsabilizarse de sus propios actos, según reza la egoísta definición actual de adulto; sino más bien de la personalidad verdaderamente madura: capaz de cuidar de los demás y responsabilizarse de ellos.

Para Homero, el primer gran educador de la Hélade, el viejo concepto guerrero de la areté (como valor, fuerza, ideal de perfección individual) no era suficiente para los tiempos nuevos. Viene a decir, con otras palabras, que los valores no son meras estrategias para la guerra, o tácticas competitivas, sino virtudes para la vida; que no sólo sirven para construir fascinantes piezas retóricas en defensa de los propios intereses (como si quisiera recordarnos que hay lideres de muy buenos principios..., pero de muy malos finales).

Álvaro de Silva, Introducción a El amor o la fuerza del sino de G.K. Chesterton, p. 40. 
O dicho de modo más actual: los valores no son sólo estrategias de ventas o tácticas para la eficacia (producir más, ganar más, vender-ser mejor...). Tampoco son simple instrucción (conocimientos teóricos para entender mejor la realidad); ni sólo capacitación (habilidades técnicas para manejar más exitosamente la realidad). Los valores, en este contexto, son formación, entendida como la adquisición de hábitos intelectuales y volitivos que nos mejoran como personas, que trans-forman nuestro modo de ser, nuestro carácter; que nos sitúan en el nivel de las grandes decisiones y nos enseñan a vivir la vida con libertad y bajo la propia responsabilidad. Son valores porque conducen hacia la propia realización de acuerdo a un ideal: plenitud, excelencia, madurez, integridad..., o eso que Aristóteles llamaba entelequia ${ }^{17}$ : como la más cumplida realización de todo el potencial de un ser.

\section{ULISES: EL HOMBRE HISTÓRICO}

En la Odisea, Homero nos presenta a Ulises, un líder muy humano que simboliza al hombre histórico, al hombre universal, cargando la herencia de una naturaleza sujeta a un principio de oposición evidente (oscilación entre el bien y el mal), aunque difícil de explicar en la cultura pagana. Explora la conciencia de Ulises, el hombre-héroe (u hombre-líder), paradoja viviente; retrata sus valores y virtudes, bizarrías y temores, flaquezas y miserias (era - llega a decir-un hombre de honor, maestro en ardides, imposturas y astucias). Esta asimétrica condición exige, según el autor, un programa formativo permanente que resalte cualidades y mitigue imperfecciones. Nos muestra cómo los valores de la vida militar (fidelidad y lealtad, genio y valor, perseverancia y paciencia, abnegación y servicio...), son también los valores de la vida doméstica.

De este modo, la Odisea se convierte en la saga del lider de un gran contingente, capaz de superar los más arriesgados trabajos, con tal de rescatar lo que les pertenece, lo más propio, los valores que más reciamente definen su identidad: fe, familia, amigos, patria.

Entelequia, técnicamente es un tipo de actualidad que pre-contiene el telos que ha de ser realizado operativamente y que, desde el inicio más primario del ser vivo, da razón de la naturaleza, unidad entitativa y ruta funcional que éste desplegará gradualmente. 
Se gesta así, en la historia de la pedagogía, un modelo de hombre educado al más alto nivel: el megalopsychos, hombre de alma grande, noble; de espíritu abierto y generoso. Es el hombre magnánimo, capaz de acometer empresas arriesgadas, dignas de honor y, con ingenio y fortaleza, llevarlas a feliz término en favor de su comunidad. Lo opuesto es el hombre pusilánime (pusillus: pequeñito, débil, esmirriado), alma pequeña, almita o peor, en despectivo almeja: hombre cobarde, mezquino y egoísta.

La formación del hombre magnánimo exige un plan formativo orientado al cultivo de pensamiento, palabra y acción, enraizado en un firme sentido ético (en su prístino y radical sentido: ethos = carácter, contextura moral de un individuo). Al lado de la acción - se afirma por medio de la figura de Fénix, el anciano pedagogo-debe estar la generosidad o nobleza del espiritu, y sólo en la unión de ambas se halla el verdadero fin de la educación: para ambas cosas, para pronunciar palabras verdaderas y para realizar acciones nobles. Esto es: no basta la presencia de los valores en el discurso, sino en la conducta.

\section{LA TELEMAQUIA}

Se comprende, entonces, por qué la crítica literario-pedagógica pudo desprender, de la Odisea, una influyente teoría educativa: la Telemaquia (Telemachou paideia: la educación de Telémaco). Según ésta, un propósito muy claro orienta la educación del púber hijo de Ulises: una formación de acuerdo con el más alto modelo de la virtud humana, es decir, la educación del líder, del caudillo de bonhomía, compromiso y pundonor.

La Telemaquia describe la relación educativa entre Telémaco y Mentor (este último encargado por Ulises del cuidado de su familia durante su forzada ausencia, y cuyo nombre ha pasado a designar al educador por antonomasia: maestro, preceptor, amigo y guía: formador de héroes). Este proceso formativo consiste, según Homero, en ilustrar la mente, suscitar la reflexión y vigorizar la acción libre, eficaz y gozosa de Telémaco, como hombre y como líder. No faltan, en este modelo educativo, los consejos de experimentados amigos; el influjo amorosamente exigente de la madre; el recio ejemplo del padre ausente, cuya presencia espiritual actúa como factor educativo capital. Viajes y experiencias de vida encaminan al discípulo 
a encarar nuevas situaciones, retos difíciles, ambientes diversos en los que aprende a alternar con prominentes y a ejercitar una respetuosa consideración para todos los hombres. Tampoco falta, al menos como necesidad y deseo, el hálito protector de una fuerza divina que le orienta, impulsa y sostiene. Gracias a este programa educativo, Ulises reencontrará a su hijo convertido en un joven caudillo sabio, discreto, prudente, sobrio y digno de toda confianza.

Así se explica que la Odisea haya inspirado, por ejemplo, en el siglo XVII, la llamada educación de príncipes. Dentro de ella, Bossuet deriva su plan formativo para el Delfín, hijo de Luis XIV. Fenelón la emplea para esbozar la educación contenida en Las aventuras de Telémaco, obra destinada originalmente a la reorientación del enfant terrible: el duque de Borgoña, y posteriormente muy leída por la juventud francesa. Inspira a Locke en el diseño de la educación del gentleman inglés. James Joyce, por su parte, formula una versión moderna y paródica (Ulises, 1922), representante del simbolismo múltiple, donde el legendario Ulises se encarna en el personaje de Leopold Bloom. Y da lugar, también, al Ulises Criollo (1936), célebre ensayo literario que exhibe el mesianismo panamericano enarbolado por José Vasconcelos.

\section{DE MAL EN PEOR}

Según la Odisea, consumada la caída de Troya (narrada en la Ilíada), los griegos, guiados por Ulises, emprenden el regreso a su patria. Pero los dioses, celosos de su triunfo, se declaran sus enemigos. Veinte años durará su riesgosa travesía saturada de peligros. Aunque en la lucha contra sus enemigos Ulises no pierde la vida como sus compañeros, es el que más tiene que soportar la ira de los dioses.

Convertidos en metáforas, los mitos que pueblan la Odisea parecen querer denunciar los monstruos que alejan al líder de su familia y de su vocación humana. Los Lotófagos, por ejemplo, que mediante engaños hacen que Ulises coma la planta de loto que provoca el olvido; o Polifemo, el cíclope, trabajador obsesivo dedicado al pastoreo que encarcela a los hombres para cruelmente devorarlos. ¿Simbolizan, acaso, el activismo y el laborismo (exceso de reuniones, trabajo a deshora, viajes, banquetes, clubes, 
casinos...), causantes del llamado workaholic: adicto autocaníbal, neurotizado por un trabajo tomado como fin único, como un Valor Supremo, que lleva a olvidar cualquier otro compromiso o responsabilidad anterior y libremente asumido?

O Circe, la gran hechicera, que convierte en cerdos a quienes se rinden a sus encantos; o las Sirenas: monstruos mitad mujer y mitad pez, que habitan entre los arrecifes y atraen a los navegantes con sus dulces cantos para hacerlos naufragar. ¿Personifican, quizá, el egoísmo, la frivolidad, la vanidad, capaces de seducir incautos hasta hacerlos zozobrar entre los escollos del consumismo, materialismo, triunfalismo y todo lo que se entiende por vive la joie?

Entre esta galería del horror, dos monstruos enfatizan la labilidad del héroe solo, alejado de los suyos y expuesto a los riesgos del vivir: Caribdis, vorágine terrorífica que tragaba a los navegantes entre pavorosos rugidos; en el remoto caso de que alguien escapase del remolino fatal, sería atrapado y destrozado por Escila, reptil monstruoso de seis cabezas que habitaba en una cueva marítima próxima. De ahí la frase «estar entre Escila y Caribdis», es decir, pasar de un mal a otro peor.

\section{... Y VIVIERON MUY FELICES}

Tales monstruos cobraron la vida a los compañeros de Ulises, pero éste es salvado por Calipso, la ninfa enamorada del héroe. Él, deseoso de un poco de descanso y consuelo, acepta quedarse con la bella sólo un poco, pero ella logra retenerlo ¡durante ocho años! (¿quiere esto simbolizar las imposturas del pobre, versátil e impredecible corazón humano, que cree poder descuidar un poco la vigilancia y permitirse alguna distracción? Y se dice: ¡Es sólo un momento! ¡No saldré de mis casillas!; ¿sólo una ojeada por encima de la reja? ${ }^{18}$ ).

Con esto ¿se nos desea recordar que la tentación siempre muestra su rostro más seductor para hacernos caer? ¿Que la curiosidad se vuelve fiebre; el momento, años; la distracción, delirio; y la ojeada, traición? ¿Que

${ }_{18}$ Albino Luciani, Ilustrísimos señores, p. 66 y ss. 
nadie despierta voluntariamente la pasión sin hacerse su prisionero? ¿Que en ese jugueteo pasional, el cazador suele ser cazado? ¿Que el que cede en poco, cede poco a poco?

En fin, Atenea suplica a Zeus que levante su castigo a Ulises. Éste, tras numerosos días de navegación, es arrojado por Poseidón a una isla donde es rescatado por Nausica, hija de Alcinoo, rey de la isla. La joven, más prudente, conduce a Ulises ante su padre, no sin indicarle: No vayamos juntos. Quédate atrás. La gente tiene lengua fácil. Si ven a un hombre a mi lado, tal vez pensarán mal y hablarán peor. Ulises atiende el consejo y, escondido en un barco, es conducido a Ítaca.

Disfrazado de mendigo, el héroe busca a su hijo Telémaco. Éste le cuenta que durante su larga ausencia, Penélope, su esposa indisolublemente fiel en la prosperidad y en la desgracia ${ }^{19}$, rechazó cuantas ofertas de matrimonio le ofrecían quienes lo creían muerto. Ella, igualando a su marido en astucia, había declarado que elegiría esposo el día en que acabase el tapiz que estaba tejiendo. Pero por la noche deshacía lo tejido durante el día, hasta que una sirvienta denunció su estratagema. A punto estaba de finalizar el tapiz cuando Ulises se presentó en palacio y, junto con Telémaco, venció y expulsó a todos los pretendientes. Penélope reconoció a su marido gracias a una cicatriz y, según la versión tradicional, vivieron muy felices ${ }^{20}$.

\section{ULISES Y LA NOSTALGIA DE LA FAMILIA}

Al salir victorioso de Troya, Ulises era feliz, pero abrigaba una gran nostalgia de su hogar, la rocosa Ítaca, de su esposa Penélope, de su hijo Telémaco y de su pueblo. Muchas veces, el desánimo le tentó con renunciar a la lucha, pero la esperanza y el deseo de ver aunque sólo fuese de lejos el humo de la chimenea de su casa, le daban nuevas fuerzas.

${ }^{19}$ Ibid., p. 64.

${ }^{20}$ Según otra versión, tiempo después Ulises muere a manos del hijo de Calipso: Telégono, quien ignorando que el héroe era su padre, lo atravesó con una jabalina, cumpliéndose así cierta profecía. 
Del griego nostós, nostalgia significa «deseo de un retorno feliz», «vivo deseo de volver salvo a casa o a otro lugar familiar»; y de algia, algós = dolor; traducción del alemán Heimweh: «Dolor por no estar en casa»; «sufrimiento por estar separado de la propia familia o casa»; un cierto dolor que, a la vez, preludia la felicidad de llegar a donde alguien nos espera. Un término afín es añoranza: «Recuerdo doloroso y dulce a la vez», «sufrimiento dulzón por una persona o cosa ausente y muy querida». La nostalgia de la casa - dice Yepes-es fortísima en el hombre, porque significa nuestro propio origen, nuestra familia ${ }^{21}$.

Esta nostalgia, en un carácter fuerte como el de Ulises, aguza la mente, tonifica la voluntad y da sentido a la aventura. En cambio, en espíritus pusilánimes, puede convertirse en desaliento, desesperación y miedo. Miedo que, en una sociedad en declive porque no mira el futuro con esperanza, y reacia a los lazos duraderos y exclusivos, se manifiesta en esa mentalidad que necesita planificarlo todo, que cree poder planificarlo todo, sin capacidad ni deseo de sorpresas, paralizada por el miedo a un futuro que no está en nuestras manos controlar ${ }^{22}$.

Es, en el fondo, la inseguridad pesimista que se expresa mediante intrigas, falsas alarmas y engañosas creencias. Por ejemplo:

\section{- ¿Cree que la Familia es un Obstáculo para el Progreso Económico de los Pueblos?}

Pues... para la pedagogía del liderazgo, parece ser todo lo contrario. Por ofrecer sólo un ejemplo, y por sorpresivo que parezca, en la actualidad se considera que: La escasez de nacimientos es ya motivo de preocupación general en Occidente y Japón. Pero existe una gran excepción a la crisis: Estados Unidos, donde la fecundidad ha remontado hasta situarse cerca del umbral de reemplazo de generaciones (2.1 hijos por mujer). Cada vez más analistas ven ahi una clave importante de la superioridad de la economía norteamericana sobre la europea.

${ }^{21}$ Ricardo Yepes, Fundamentos de antropología, p. 111.

${ }^{22}$ Ignacio Aréchega, vid. Aceprensa, «Encuentro mundial de las familias». 
Examinada desde otro ángulo, también resulta que, a la postre, la creencia de que la familia es un lastre para el progreso, ha causado graves estragos para el género humano. Es el prejuicio que ha llevado a las grandes dictaduras (ideológicas, políticas, de modas o de precios) a propugnar un mal disimulado menosprecio por la institución familiar. Es el prejuicio que hallamos en la base de todos los regímenes abierta o veladamente totalitarios. En la ex Unión Soviética, por ejemplo, la revista Pravda llegó a declarar: El hombre ha descubierto un nuevo parentesco que no es el de la familia, ni del hogar, ni de la sopita humeante. [Un parentesco] con la máquina a la que ha aprendido a amar, y con la máquina, al trabajo, a la revolución. Fue así como se excluyó a la familia de toda función educativa porque: No puede haber colaboración entre hogar y escuela: con la nada no se puede colaborar; la familia no tiene nada que ver en este asunto pues, habiendo perdido [los padres] su aptitud educadora por su impotencia radical, no deben sino felicitar al Estado por ejercer sobre sus hijos una providencia que sabe satisfacer todas sus necesidades ${ }^{23}$. Así se obligó a los padres a renunciar a su derecho a educar a sus hijos para cederlo al Estado.

En las antípodas ideológicas, en ambientes capitalistas dominados por el laborismo y el consumismo, a causa del mismo prejuicio, la familia sólo es valorada a partir de un principio no expresado de cálculos de los costes; el número de los hijos, a veces hasta su misma presencia, y el lazo conyugal se ven como pesos, pérdidas y obstáculos para la realización de sí y la liberación de la cárcel doméstica ${ }^{24}$. La vida familiar y sus valores pierden significado para dar paso a valores meramente instrumentales y utilitarios.

También la historia de la pedagogía nos recuerda que la familia: $\mathrm{Ha}$ sido la célula principal y la unidad central de casi todas las sociedades que han existido hasta ahora, con excepción, la verdad sea dicha, de algunas sociedades como aquella de Lacedemón, que optó por la «eficiencia» y que, en consecuencia, pereció sin dejar ni rastro ${ }^{25}$.

\footnotetext{
${ }^{23}$ François Charmot, Esbozo de una pedagogía familiar, p. 16.

${ }^{24}$ Santelli, L. Beccegato, Voz: «Familia», Diccionario de ciencias de la educación, p. 966 y ss.

${ }^{25}$ G.K. Chesterton, op. cit., p. 66.
} 
En suma: esta creencia o prejuicio ha resultado una triste constatación de que en muchos aspectos, el becerro de oro es de palpitante actualidad en nuestro mundo ${ }^{26}$. El peligro simplemente está ahí porque, convencida la multitud de que el progreso material y social es la suprema felicidad, y que la familia es un engorro, es fácil convencerla también de practicar un eugenismo ${ }^{27}$ proporcionado a los propios recursos, y de confiar la educación de los hijos, convertida en función burocrática, a hábiles pedagogos-economistas al servicio del Estado. De ahí surge la absurda creencia de que todo el mundo (profesores, pedagogos, psicólogos, orientadores, consejeros, trabajadores sociales, etcétera) ¡conoce, comprende, ama y sabe educar a los hijos, menos sus padres!

Con razón Chesterton incluye, entre las causas externas del deterioro de la familia, no sólo a Moscú, sino también a Manhattan ${ }^{28}$.

\section{- ¿Cree que la Familia se Opone al Progreso Profesional de las Personas?}

¡Cuidado! Antes de contestar recuerde que: cualquier creencia demasiado repetida puede formarnos buenos o malos hábitos.

Veamos: si la célula esencial de la sociedad y de la sociabilidad es la familia, es natural que ese primer orden fundamental sea el mejor para aprender y ejercitar las virtudes humanas fundamentales que, en su momento, redundarán en un mejor desempeño social y profesional. Sólo en el seno de la familia crece la relación adecuada entre los sexos y entre las generaciones... [Por algo] la educación familiar significa introducir al otro correctamente en su libertad, de forma que aprenda sus leyes internas, que aprenda a ser persona. Aquí, la obediencia está al servicio de este entrenamiento en la propia libertad. Y, viceversa, exige lógicamente a los hijos

${ }^{26}$ Joseph Ratzinger, Dios y el mundo, p. 158.

27 Eugenes: mejoramiento de la raza.

${ }^{28}$ Cfr. G.K. Chesterton, op. cit., p. 27. 
aceptar dicha educación... Los hijos ven en los padres, la realización de la persona ${ }^{29}$.

No extraña, pues, que la pedagogía empresarial asegure que, por muchos cursos de capacitación, actualización, perfeccionamiento, etcétera, que se imparta al personal de una organización, sigue habiendo virtudes y valores que nunca alcanzarán un desarrollo suficiente si no están enraizados en la educación familiar: sentido de solidaridad; espíritu de servicio y cooperación; veracidad y credibilidad; lealtad y amistad; sencillez y humildad para enseñar a otros con generosidad; serenidad para que la actividad intensa no se convierta en activismo; respeto, cuidado y mejor aprovechamiento de los materiales e instrumentos de trabajo; y hasta esa alegría que revela inteligencia, familiaridad y es síntoma de bondad, generosidad y capacidad de crear un ambiente positivo para el trabajo.

De ahí que las más importantes escuelas de negocios en el mundo, incluyan en sus planes de estudios, sesiones de discusión, estudio, investigación y otras actividades formales e informales, tendientes a hermanar las esferas laboral, familiar y personal de sus cuadros directivos, administrativos y operativos. De otro modo, quedarían a la zaga de las aspiraciones y necesidades de hombres y mujeres profesionales, y de la empresa de hoy.

Cuando en la empresa existe una verdadera cultura familiarmente responsable - señala Santiago Mata-, el resultado es la mejora y cohesión de una plantilla laboral de calidad... Donde el Estado no llega, surgen iniciativas sociales para compatibilizar trabajo y familia. Instituciones como el Grup d'Entitats Catalanes de la Familia, la Comunidad de Madrid y varios ayuntamientos premian anualmente a empresas que fomentan la conciliación entre familia y trabajo... El IESE (Instituto de Estudios sobre la Empresa) ha desarrollado el concepto de Empresa Familiarmente Responsable (EFR), donde la «efe» podría traducirse también por flexibilidad: la empresa es «responsable» cuando es flexible para adaptarse a las necesidades familiares de sus empleados. Pero al fin y al cabo son éstos (incluidos los directivos), los responsables

${ }^{29}$ Joseph Ratzinger, Dios y el mundo, p. 161. 
de sus familias y los primeros que tienen que ejercitar, personalmente, la flexibilidad para compatibilizar distintas exigencias ${ }^{30}$.

Familia y trabajo son valores interdependientes a tal grado que Kim B. Clark llega a señalar que: No se puede ser un líder con integridad si se actúa de una forma en el trabajo y de otra en casa. Por ejemplo, si un líder falla en su responsabilidad con la familia -aquellos que más le deben preocupar-, ¿cómo podemos confiar en que se hará responsable de las personas que emplea? Si él asegura que las personas son su mayor prioridad, pero no dedica tiempo a sus propios hijos, ¿por qué hemos de creer en sus promesas laborales? Si apoya la honestidad y la transparencia en la compañía, pero es deshonesto en el trato con su familia, sus palabras suenan falsas ${ }^{31}$.

\section{- ¿Cree que los Vínculos Familiares son Cadenas que Coartan la Libertad Personal?}

Un examen atento y detenido de la experiencia común, nos revela que la puerta más a mano para salir a la conquista del mundo es, justamente, el plexus sistémico natural formado por los vínculos familiares. No siempre lo reconocemos, pero el ser autoperfectible y sociable del hombre encuentra, en la convivencia doméstica, la primera escuela de libertad.

Si lo vemos bien, una familia sana es la primera en procurar lo mejor para sus miembros. Ya lo hemos dicho: los hijos ven, en sus padres, el modelo de la realización correcta de la persona. Dentro de sus posibilidades - materiales y culturales-, y a pesar de eventuales altercados y equivocaciones, los padres buenos se esfuerzan por proporcionar a sus hijos lo necesario para que estén bien alimentados, crezcan llenos de salud, mejoren en sus estudios, tengan buenos amigos, descubran su camino en la vida y lo sigan con honor hasta alcanzar una vida recta y lograda ${ }^{32}$. Son también, los padres, quienes primeramente transmiten a sus hijos, más por

${ }^{30}$ Santiago Mata, «Conciliar familia y trabajo sin malabarismos: La clave es la flexibilidad de las empresas», Aceprensa, núm. 10/05.

${ }^{31}$ Kim B. Clark, «Liderazgo, valores y educación en un mundo atribulado», febrero 2005.

${ }^{32}$ Robert Spaemann, Ética: cuestiones fundamentales, p. 52. 
imitación que por enseñanza, hábitos de aseo, orden, convivencia, paciencia, generosidad, alegría... En suma, los ayudan a aprender a estudiar, a trabajar, a ser hombres o mujeres de bien. No en vano se afirma que la felicidad de una persona depende de la familia que tiene ${ }^{33}$.

Por algo el hombre es, de origen, un ser vinculado. Su naturaleza es existir y coexistir, vivir y convivir. $Y$ ese coexistir es su mismo existir. Por eso: El anhelo de unión interhumana es la aspiración más poderosa de la persona. Es el anhelo fundamental, la fuerza que mantiene unida a la raza humana, al clan, la familia y la sociedad. Su fracaso significa la locura o la aniquilación - autoaniquilación o aniquilación de los otros ${ }^{34}$. Sin vínculo, la humanidad no existiría ni un solo día.

Únicamente gracias a los vínculos — primero los vínculos familiaresle es posible al hombre subsistir, lograr sus fines temporales y acercarse al perfeccionamiento de su naturaleza. Romper esos vínculos no es rebeldía, es deserción, es traición: es renunciar a sí mismo. Disolver los lazos no es emancipación, es huida. Otra cosa es, en su momento, salir del círculo doméstico para seguir el propio camino. Esto no es renuncia, es fidelidad a una llamada: la llamada a proyectarse hacia afuera.

Por lo demás, los vínculos familiares, cuando son sanos, contribuyen a configurar los rasgos esenciales de una personalidad equilibrada, dispuesta a un mejor desempeño profesional. Las excepciones, por numerosas que sean, no deben tomarse como norma general. Cuando la excepción se vuelve norma, de los lazos familiares se exagera su condición de cadena y se minimiza su condición de fortaleza, de protección. Por eso, disfrazada de derecho, se promueve la «independencia» del individuo, no para liberarlo (independencia y libertad no son lo mismo: ser independiente no significa ser libre), sino para que, in-dependizado, tenga un solo dueño: la economía politizada o política economizada. Nótese cómo en un mundo mercantilizado, la familia es vista como el Gran Enemigo que impide la comercialización del placer y la explotación de la debilidad humana.

${ }_{33}$ Ricardo Yepes, Fundamentos de antropología, p. 287.

${ }^{34}$ Erich Fromm, apud. Joseph Ratzinger, op. cit., p. 175. 
Desde luego que las relaciones humanas no son siempre fáciles y placenteras. También la convivencia familiar entraña, con frecuencia, múltiples y graves problemas. El home sweet home es un lema bonito, pero azaroso. Pero ese intríngulis es parte del aprendizaje. Aprender a ser libre no significa no tener problemas, sino aprender a superarlos. Sacar la vuelta a los problemas no es libertad, es evasión.

También es cierto que, junto a problemas reales, hay otros que lo son sólo en apariencia. ¿Quién no conoce el caso del cónyuge molesto, dispuesto a romper el vínculo matrimonial, debido a la injusta carga que le impone el compromiso de fidelidad? Se olvida que, en efecto, nadie está obligado a prometer fidelidad a otro, pero que, si lo ha hecho -y no estaba dormido o ebrio-, ese otro tiene derecho a contar con su fidelidad ${ }^{35}$. Y conocemos también a esa madre amorosa que, por no contrariar los gustos del hijo, lo alimenta únicamente con bombones y televisión. ¿Es que no se da cuenta de que está haciendo exactamente lo que haría alguien que quisiera dañar gravemente a su nene? ${ }^{36}$. ¿O el caso de ese adolescente, a punto de huir del hogar porque su padre lo ha reprendido con ira? ¿No sabe que la ira no necesariamente se opone al amor? A veces los padres deben reprender con ira a su hijo precisamente porque lo aman. Y no cumplirían con su obligación y su deseo de amar si, por ponérselo fácil al otro y también a símismo, no intervinieran a veces críticamente en su vida, si no lo corrigieran. Sabemos que, a menudo, los niños malcriados, a los que se les ha consentido todo, al final no logran salir adelante en la vida, porque ésta les trata de otra manera y no han aprendido a disciplinarse a sí mismos, a situarse en el buen camino ${ }^{37}$.

Es verdad que son los cónyuges quienes se prometen mutua fidelidad, pero ésta es una virtud que todos podemos y debemos vivir en todas nuestras relaciones: fraternidad, amistad, compañerismo, escolaridad, profesionalidad, ciudadanía, etcétera. Ser fiel significa mantener una promesa; cumplir el compromiso libremente aceptado; empeñarse en acabar una misión en la que uno se ha comprometido o una tarea que nos ha sido encomendada. Es la fidelidad una manera de amar, en el sentido de

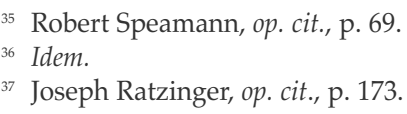


procurar el bien del otro. Con frecuencia nos preguntamos: ¿Cómo puede el ser humano, que es mudable, débil y cambiante, ser fiel a los compromisos? La respuesta cristiana es: Porque su fidelidad está sostenida por Aquel que no es mudable, ni débil, ni cambiante: Dios.

Recordemos que la pretensión de una «familia perfecta» es un sueño que se puede convertir en pesadilla; y que tratar de romper los lazos familiares, suele ser una pesadilla que suele convertirse en tragedia.

\section{- ¿Cree Usted que la Familia es Obsoleta?...}

¿... condenada a desaparecer como cosa del pasado, imposible según las exigencias de la vida moderna, sobre todo después de las revoluciones del siglo XX: laboral, sexual, femenil, juvenil...?

Sin embargo, al parecer, la mayor prueba de que la familia es el sustento más firme de la civilización, la moral y el humanismo, son los ataques de que es objeto. Ataques que no se dan sólo en algo superficial, ni siquiera en algo tan inmortal como la «guerra de los sexos», sino que se dirigen a la naturaleza misma de la familia: su origen, estructura, fines y funciones. Es la existencia natural de la familia como el ideal de la convivencia humana y como fundamento de la sociedad lo que se desea destruir ${ }^{38}$. Los ataques llegan por diversos frentes: a través de revistas, de escándalos llamativos a los que se da una especial publicidad, de seriales de televisión que alcanzan a un gran público que poco a poco va deformando su conciencia...

Deformada la conciencia y perdida la capacidad valorativa (anaxia), es fácil que las masas acepten que los valores familiares (conyugalidad, paternidad, maternidad, filiación; compromiso, estabilidad, fidelidad...) sean sólo un mito impertinente, chiste cruel u obscenidad que ofende a los oídos modernos, por lo cual no deben mencionarse en círculos respetables ${ }^{39}$. Así: amor, matrimonio, sexo, familia y su función formativa quedan reducidos a

${ }^{38}$ G.K. Chesterton, op. cit., p. 18.

${ }^{39}$ Ibidem, p. 22 y ss. 
meras banalidades. (El mundo del espectáculo — política, cine, TV...- es rico en ejemplos: personas que juegan a que se enamoran, se casan, tienen hijos, se divorcian; se vuelven a enamorar, a casar, a tener otros hijos, a divorciar...).

Por muy líder que sea, el humano es y seguirá siendo hasta que se muera, un ser familiar, por indigencia y por excelencia. Necesita de su familia y su familia necesita de él. Es mucho lo que debe recibir, y es mucho lo que debe aportar. Educadores, escritores, politicos y legisladores han de tener en cuenta que gran parte de los problemas sociales, y aun personales, tienen sus raíces en los fracasos o carencias de la vida familiar ${ }^{40}$. Porque la existencia de la familia - como institución natural, humana y divina, célula de la sociedad y germen de la sociabilidad- es un hecho previo a cualquier pacto, contrato, teoría o reconocimiento estatal. La gente no nace en una guardería infantil y tampoco muere en una funeraria. El papel de la familia seguirá siendo entendido en términos de aportación, intervención y responsabilidad en la construcción de un futuro histórico, individual y social que, de alguna manera, depende de nuestras decisiones presentes ${ }^{41}$. Como es la familia, así es la sociedad, porque así es el hombre de modo que el conjunto de las relaciones que se instauren en la humanidad depende radicalmente de las que se establecen en el seno de la familia... ${ }^{42}$. Ésos son los hechos y de ellos hay que partir.

En efecto: pertenece a la esencia del homo familiaris nacer en una familia y, por lo general, está llamado a fundar una nueva. La propagación de la especie humana y el mantenimiento de sus valores, exigen que la familia siga siendo la comunidad instintivo-natural, socio-cultural y ético-religiosa más estable e irremplazable para que sus miembros en comunidad de vida y amor- hagan frente a las necesidades materiales y espirituales de la existencia y, solidariamente, construyan el progreso integral y armónico de la sociedad.

40 Francisco Fernández Carbajal, Hablar con Dios, t. III, p. 476 y ss.

${ }^{41}$ Ana Ma. Navarro, «Papel de la familia en el futuro», Lo permanente y lo cambiante en la educación, p. 95.

${ }^{42}$ Tomás Melendo, «La familia en la Universidad», Istmo, 279, p. 52. 
La salud, y hasta la vida misma de la sociedad, dependen del mantenimiento y fomento de los valores familiares. De hecho, cualquier debilitamiento de la estructura familiar produce una correlativa desaparición del impulso para mantener y fomentar los valores que determinan la elevación cultural de un país ${ }^{43}$. La familia es y seguirá siendo, el signo de esperanza que necesitan los hombres y que necesita el mundo. Antes, como ahora, sólo se educará bien a la nación si se respeta la primacía espiritual y social de la familia y se protege a ésta en el libre uso de sus derechos ${ }^{44}$.

Es verdad que las tensiones y divisiones de la posmodernidad oprimen a la familia del siglo XXI. La familia nuclear, típica de las sociedades industrializadas contemporáneas, se halla cada vez más expuesta a procesos de desintegración. En Europa, por ejemplo, cuna de la civilización occidental, existen países en los que cerca del 70\% de la población está integrada por hombres y mujeres que viven solos. Incluso el término «familia» sirve hoy para englobar fenómenos tan distintos como el matrimonio de padre y madre con hijos, las parejas no casadas, las familias recompuestas tras un divorcio, la maternidad en solitario o las parejas homosexuales. Sin duda, en toda sociedad habrá siempre distintas situaciones familiares, arreglos y desarreglos, fruto de vicisitudes personales, a veces provocadas, otras padecidas. Pero existen ya suficientes datos y experiencias para observar que determinados modelos de familia contribuyen a estructurar la sociedad, mientras que otros son fuente de problemas ${ }^{45}$.

Por eso, para Chesterton, la familia ni es obsoleta, ni mucho menos ha muerto: Está, quizá, medio enterrada en el polvo de la frivolidad y en el barro de la insensatez y el egoísmo, que parecen ser congénitos a la humanidad y que nunca dejan de acompañarla en su caminar. En términos de cálculo estadístico, la familia languidece en las sociedades tecnológicamente más avanzadas del globo. Pero, como todas las cosas grandes de verdad, como todas las realidades

${ }_{43}$ Ángel Rodríguez Luño, Ética.

${ }^{44}$ François Charmot, Esbozo de una pedagogía familiar, p. 14.

${ }^{45}$ Ignacio Aréchega, Aceprensa, «Encuentro Mundial de las Familias». 
que de verdad importan, la familia «semper reformanda», está siempre muriendo y siempre resucitando ${ }^{46}$.

\section{- ¿Cree que la Familia no se Adecua a la Cultura Moderna?}

Chesterton, hiperbólico como era, inició, en cierta ocasión, una conferencia acerca de la familia y el pensamiento moderno, diciendo: Tal vez sería más apropiado hablar sobre la familia y la ausencia moderna de pensamiento. Hacía referencia, sin duda, a la falta de solidez en la argumentación de los ataques que se hacen, so pretexto de modernidad, a la institución familiar. Con ironía y sentido común, reduce a tres las maneras típicas de la modernidad: Una consiste en decir ¡no habrá niños! Esta sugerencia puede hacerse al individuo, pero se hace de hecho a todos los individuos. Otra es que el padre envie a los niños inmediatamente, sobre todo si son muchachos, a una escuela distante e inaccesible, con límites como una prisión, para que esos pequeños puedan llegar a ser hombres de una forma que es considerada imposible en la compañía de sus propios padres. Pero está cesante este método «moderno», y hasta los mismos modernos se han dado cuenta de que es algo anticuado. La tercera es impecablemente moderna, y consiste en imitar a Rousseau, que dejó a sus hijitos en el portal de una casa para niños abandonados. El problema de tales métodos es que pueden ser llevados a cabo ${ }^{47}$.

Con esto se quiere decir que, con la cultura moderna, la humanidad mucho ha ganado, pero también mucho ha perdido. Pero ¿qué se entiende por «cultura moderna»? Porque, por lo general, lo que llamamos «moderno» muy pronto se vuelve anticuado. Le ocurre lo mismo que a la llamada «música de moda», que por muy poco tiempo dura de moda.

Hablar de cultura moderna es aludir, entre otras cosas, a ciertas condiciones de vida neurotizantes que caracterizan los grandes conglomerados urbanos; de los ambientes rurales, descentralizados o periféricos, donde un ritmo de vida se acompaña de carencias y conformismos

${ }^{46}$ Álvaro de Silva, apud. El amor o la fuerza del sino, G.K. Chesterton, p. 19.

${ }^{47}$ G.K. Chesterton, op. cit., p. 55. 
paralizadores y gravemente lesivos de la realidad individual, familiar y social ${ }^{48}$. Es hablar, también, de la gran cantidad de familias devastadas por los fenómenos migratorios que ya alcanzan proporciones incontrolables.

Es aludir, igualmente, a una cultura acostumbrada al «si no queda satisfecho, le devolvemos su dinero», en la que lo «alternativo» reivindica sus derechos... Si la unión entre hombre y mujer se entiende sólo como un «vamos a ver si esto funciona» y no como un amor para siempre; si los hijos son un extra optativo; si no se está dispuesto a sacrificar ninguna aspiración individual en bien de la familia, se comprende que para muchos, hoy, el matrimonio sea sólo una formalidad prescindible, no mejor que la mera cohabitación sin compromiso ${ }^{49}$.

Fobia al compromiso y falta de comprensión de la naturaleza de la familia, es lo que ha conducido a la cultura moderna a ensayar, sobre todo después de la contestación de los años sesenta, fórmulas nuevas y modelos alternativos de convivencia más libre y cómoda: comunas que pretenden superar otras relaciones comprometidas y posesivas; kibbutz y macrofamilias, que permitan vivir cada momento existencial - sexual, afectivo, económico y educativo- en el ámbito del grupo en el que se diluye la responsabilidad.

Sólo que en la práctica, esas nuevas maneras de asociación no han podido dar respuesta satisfactoria a las expectativas de renovación. No obstante, a pesar de su precariedad e insuficiencia, esas formas amenazantes de la familia, la civilización y el humanismo, regresan de tanto en tanto disfrazadas de progreso y libertad.

Se explica, entonces, que muchos de los rasgos que perfilan la cultura moderna se orienten a erosionar los fundamentos de la familia y de la moral, propagando la permisividad moral: los divorcios, el amor libre, el aborto,

${ }^{48}$ L. Santelli Beccegato, vid. Voz: «Familia», Diccionario de ciencias de la educación, p. 966 y ss.

${ }^{49}$ Ignacio Aréchega, loc. cit. 
la anticoncepción, los atentados a la vida en su fase inicial y terminal, así como su manipulación. Estas corrientes disponen de enormes medios financieros, no solamente en cada nación sino también a escala mundial. En efecto, pueden contar con grandes centros de poder económico, a través de los cuales tratan de imponer sus condiciones a los países en vías de desarrollo. Por eso, es legítimo preguntarse si no estamos ante otra forma de totalitarismo, falazmente encubierto bajo las apariencias de la democracia ${ }^{50}$.

Creer que la familia es la que no se adecua a la modernidad - concluye Chesterton-obedece a una falta de claridad de pensamiento o un pensar cabeza abajo que pretende entender la realidad con los pies. Es poner el carro delante de los bueyes, y no al revés... La gente dice: La vida de familia no se adecua a la vida de hoy día. Esto es como decir: Las cabezas no se adecuan al tipo de sombreros que están ahora de moda. Y en lugar de agrandar los sombreros, se ponen a recortar las cabezas ${ }^{51}$.

\section{- ¿Cree que Familia y Trabajo son Valores} Antitéticos por su Mutuo Carácter Ofensivo-Destructivo?

¿Cree que toda atención a la vida familiar, va en detrimento de la vida profesional (y viceversa)?

En definitiva, contraponer familia y trabajo resulta un antagonismo artificial. Artificio que se desvanece en cuanto se reconoce que ambos compromisos son asumidos por las personas como actos maduros, conscientes, libres, y no como simple satisfacción del ego, mera obligación o apetencia coyuntural y veleidosa. No entenderlo así es arriesgarse a vivir entre la angustia y el fracaso.

Ya lo hemos dicho: cierta evidencia innata atestigua que estos dos ámbitos de valores - uno relacionado con el trabajo y otro consecuente con el carácter familiar de la vida humana- pueden y deben conciliarse y compenetrarse. El trabajo es el fundamento sobre el que se forma la vida

${ }^{50}$ Juan Pablo II, Memoria e identidad, p. 66.

${ }^{51}$ G.K. Chesterton, op. cit., p. 39. 
familiar, la cual es un derecho natural y una vocación del hombre. [...] la familia constituye uno de los puntos de referencia más importantes, según los cuales debe formarse el orden socio-ético del trabajo humano. [...] la familia es, al mismo tiempo, una comunidad hecha posible gracias al trabajo y la primera escuela interior de trabajo para todo hombre ${ }^{52}$. Otra cosa resulta si se violentan las condiciones de la familia o del trabajo.

Familia y trabajo son, naturalmente, valores complementarios: uno remite al otro. El ser humano es, a la vez, homo familiaris y homo faber. El trabajo, dentro y fuera de casa es, en un cierto sentido, una condición para hacer posible la fundación de una familia. El trabajo es un elemento fundamental para alcanzar los fines de la familia. La vida familiar y la vida profesional se sostienen mutuamente. Armonizarlas no siempre es fácil. La conciliación no se da sola, ni de modo necesario, pero forma parte importante del empeño por vivir en unidad de vida. Unidad que, cuando encuentra el apoyo debido, pone orden en el corazón, enseña cuáles son las prioridades: las personas por encima de otros intereses. Intuición, buena voluntad y darle tiempo al tiempo, no bastan. Se requiere inteligencia, decisión y esfuerzo. Preservar el ámbito familiar, exige revolucionar el ámbito laboral.

Como en toda decisión importante, los buenos resultados dependen de conocer a profundidad el fin, elegir adecuadamente los medios y persistir.

\section{- ¿Cree que la Conciliación Familia-Trabajo es una Utopía según las Circunstancias Laborales Actuales?}

Para la teoría empresarial actual, familia y trabajo son valores complementarios, armónicos y jerarquizables; ocasión de aprendizaje, maduración y desarrollo personal. Armonizarlos implica recuperar el recto sentido de libertad — como facultad de amar con amor de benevolencia- y optar por un valor fundamental, un ideal que dé sentido, unidad y coherencia a

52 Juan Pablo II, Enc. Laborem exercens, núm. 10. 
todos los demás valores. El amarás a Dios sobre todas las cosas y al prójimo como a ti mismo, seguirá siendo el mejor criterio para jerarquizar.

En esta tarea conciliatoria, las condiciones laborales también deben hacer su parte. Es tarea de la política social del siglo XXI, flexibilizar la empresa; organizar el mundo del trabajo de tal modo que se evite generar situaciones que acarreen graves tensiones familiares o incompatibles con las obligaciones del hogar: salarios insuficientes que dificulten el crecimiento y desarrollo normal de las familias; horarios que reduzcan en mucho la presencia en el hogar del padre o la madre; trabas a la actitud generosa, abierta a la vida, de muchas mujeres que quieren conciliar la dedicación a la familia con la profesión fuera del hogar; competencia laboral desleal como única vía de ascenso; viajes excesivos, etcétera. Y está obligada, también, a revalorizar afectiva y efectivamente aquellas profesiones más estrechamente ligadas a los fines propios de la familia: labores domésticas, la labor educativa, asistencia a enfermos y ancianos, etcétera.

Kim Clark, uno de los paladines en la formación de hombres y mujeres profesionales al más alto nivel, lo afirma así: Creo decididamente en la importancia de la familia. Cada año, en la ceremonia de graduación, me dirijo a 900 graduados y hablo acerca de las oportunidades en su futuro. Les menciono dos cosas acerca de su relación entre el trabajo y la familia: 1) Ningún éxito comercial puede compensar un fracaso en casa; $y$ 2) algunos de los aspectos más importantes del trabajo que harán, serán dentro de los muros de su casa. Mi consejo es que primero inviertan en su hogar ${ }^{53}$.

\section{- ¿Cree que los Enemigos de la Familia Vienen de Fuera?}

Los enemigos reales o imaginarios de la familia son numerosos. Desde luego que quienes la atacan desde fuera no es porque puedan entenderla de punta a cabo, sino porque no la entienden en absoluto: Le dan golpes a ciegas, de una manera enteramente fortuita y oportunista; $y$ muchos la echarían abajo sin hacer pausa para preguntar por qué fue, en primer lugar, puesta arriba ${ }^{54}$.

3 Kim B. Clark, idem.

${ }^{54}$ G.K. Chesterton, op. cit., p. 97. 
Pero, en la mayoría de los casos, los principales causantes del deterioro de la familia somos nosotros mismos. Deterioro que comienza cuando empezamos a sentirnos extraños en nuestro hogar, cuando comenzamos a vernos como meros abonados, como visitas. La causa de ese extravío suele ser, apunta Chesterton, uno mismo. Las causas son: la falta de desarrollo interior, la pobreza de espíritu, el aburrimiento y la frivolidad, la asombrosa ausencia de imaginación, lo que lleva a hombres y mujeres a desesperar de la familia, o por lo menos, de su familia tal como la experimentan. La familia no es pequeña, es el alma de algunas personas la que es raquítica. La familia resulta demasiado grande para ellas ${ }^{55}$.

Se sabe que cuando preguntaron a Franco Zeffirelli, el famoso cineasta italiano, ¿cómo se destruye un hogar?, él respondió: La destrucción de un hogar comienza por minucias: pequeñas traiciones, minúsculas estupideces, diminutos malentendidos, insignificantes descuidos... Si se quiere que el amor perdure —añadía一, hay que atacar esas pequeñeces desde el principio. De otro modo - afirmaba cierto poeta- llegan a convertirse en el estupidísimo deporte de estar buscándole defectos al otro... ipara, en el momento que más le hieran, echárselos en cara!

En sentido contrario, resulta aleccionadora la actitud de Peter Lynch, el líder empresarial que comenzó su cadena de ascensos y éxitos como caddy, y llegó a ser un magnate con un fondo en Bolsa cercano a los trece mil millones de dólares (que en aquel tiempo era mucho más dinero que ahora), a tasas de rendimiento elevadísimas. De pronto, estando en el clímax del éxito, sorprendió al mundo al anunciar su retiro, según dijo, por estar harto de dedicar 14 ó 15 horas diarias a los negocios, con el consiguiente abandono de su familia y deterioro de la salud: Me voy - expresó- porque no he sabido de nadie que en su lecho de muerte se haya arrepentido de no pasar más tiempo en su oficina.

El bien de la familia en todos sus aspectos, debe ser una de las preocupaciones fundamentales de toda la sociedad $\mathrm{y}$, muy en especial, de todo cultivador de la pedagogía individual y de la pedagogía social; y de todo líder con valores, en lo que tiene de miembro de una familia y formador de 
personas: Desde los diversos sectores de la vida social hay que apoyar el matrimonio y las familias, facilitándoles todas aquellas ayudas de orden económico, social, educativo, politico y cultural que hoy son necesarias y urgentes para que puedan seguir desempeñando en nuestra sociedad sus funciones insustituibles ${ }^{56}$.

\section{Familia: ¡Llega a Ser lo que Eres!}

Es improcedente hablar de reforma — señala Chesterton- si no se atiende antes a la forma. Reformar la familia exige, previamente, saber qué es la familia, cuál es su forma esencial. No obstante, nuestro mundo desvía la atención para no penetrar en el complejo papel originante y configurador de la esencia de la institución familiar: instintivo-natural, socio-cultural, ético-religioso. Porque comprender la naturaleza de la familia no consiste sólo en atender las exigencias o vicisitudes accidentales de tal o cual unidad familiar (los llamados casos límite), por frecuentes y dramáticos que sean.

Es obvio que comprender la naturaleza de la familia —el ser, el poder ser y el deber ser- se hace cada vez más difícil por el denso «bombardeo» de mensajes heterogéneos entre sí, superpuestos y con frecuencia discordantes, vehículos de modelos de comportamiento ambiguo, respecto a los cuales se ha debilitado progresivamente una capacidad de juicio y de valoración.

A primera vista, la institución familiar está enferma. Pero, así como la enfermedad nos hace añorar con más deseo una salud que dábamos por sentada, la crisis de la familia ha de llevarnos a una nueva edición, corregida y aumentada, de lo que desea ser la realidad social, y la considerable pérdida de humanismo producida por su decaimiento bien podría terminar en una nueva y más profunda apreciación de su formidable relevancia ${ }^{57}$.

En estos momentos, rescatar a la familia no consiste en volver al pasado, sino de apostar, desde el presente, por el futuro. El lema de esta «odisea»

${ }^{56}$ Cfr. Familiaris Consortio, núm. 45.

${ }^{57}$ G.K. Chesterton, El amor o la fuerza del sino. En la Introducción escrita por Álvaro de Silva, p. 19. 
no debe ser: ffamilia, vuelve a ser lo que eras!, sino el de: ffamilia: llega a ser lo que eres! ${ }^{58}$.

Por eso, la gran odisea del siglo XXI consiste en rescatar a la familia como:

\section{- Primera escuela del amor, unión y libertad}

La conquista del amor, de la unidad y de la libertad, es tanto un proyecto personal como familiar. La familia es creación del amor, y participa de sus notas. Fecundidad, universalidad y actitud resolutoria son notas esenciales del amor, que también pueden definir a la familia: el amor le da vida y la prolonga. La familia es un ser vivo, como el amor, y por ello tiene, como todo ser vivo, cuerpo y alma. El hogar, vivificado por el amor, participa de sus notas que lo hacen espiritual, personalizador y diferenciador de cada sujeto, dándole los medios para expresarse y trascenderse hacia Dios, los demás y las cosas ${ }^{59}$.

Como ya dijimos: esto hace que la vida familiar sea la vía más inmediata para la salida del egoísmo y adquisición de los valores sociales básicos. Mientras que otras instancias tratan de fomentar los valores por instrucción, la comunidad familiar realiza la primera transferencia de los valores por identificación.

Y quien dice comunidad dice orden, y el orden implica autoridad que, debidamente ejercida, enseña que obedecer y mandar, en familia, consiste en servir libremente y por amor. Padres posesivos, indolentes, ambiciosos, permisivos, etcétera, suelen suscitar reacciones antisociales. Padres con valores fomentan comportamientos sociables, aunque los hijos, de momento, no comprendan la significación del sentido social. Junto a padres afectuosos, los hijos no sólo experimentan calma y seguridad, también aprenden a tener confianza y la satisfacción que ofrece una vida ordenada, apacible y generosa.

${ }^{58}$ Idem.

${ }^{59}$ Cfr. Ana Ma. Navarro, «Papel de la familia en el futuro». Apud: Lo permanente y lo cambiante en la educación, p. 98 y ss. 
Amor, libertad y unidad se encuentran, primero, en una familia sana, en una familia con valores. El niño aprende, sobre todo de la madre, la sonrisa social, y por ella llega a establecer el contacto social. En casa se aprende a vivir y convivir, a dar y recibir, a hablar y escuchar, a confiar y comprender. Así se realizan las primeras etapas del proceso de asimilación cultural y moral (bienes culturales, formas sociales verdaderas y valiosas; desarrollo de la individualidad, independencia y originalidad); y del proceso de superación individual (desarrollo de capacidades personales, descubrimiento y promoción del yo, hacia el futuro y hacia los demás) y, sobre todo, se adquieren las capacidades de dirigir la propia vida y hacer efectiva la libertad.

Para esto, los padres han de abrir la puerta a los jóvenes hacia todos los valores y todas posibilidades de la cultura humana, tan variada, tan laboriosa, tan elaborada. Es una ardua tarea que involucra enseñanza y ejemplo, protección y permanencia, fidelidad y esfuerzo. Sé que algunas personas —afirma Chesterton- se impacientan y se vuelven irracionales al llegar a este punto, y dicen que todo podría salir igualmente bien sin ninguna educación. Pero mienten; porque ni siquiera podrían expresar esa opinión si no hubieran aprendido laboriosamente una lengua particular en la que poder decir desatinos ${ }^{60}$.

Lo anterior justifica que la familia sea, sencillamente, familia: nunca perfecta, pero siempre el lugar privilegiado de la aceptación, de la libertad y de la caridad. El lugar donde nos pueden dejar en paz y el sitio donde preferiríamos morir ${ }^{61}$. Según Chesterton, habría que colocar la bandera de la libertad en todas las puertas y ventanas de la casa, porque cada hogar es una fuente de libertad ${ }^{62}$.

\section{- Lugar de identidad}

En la dinámica integrativa de la personalidad humana, desde la que arranca la aventura personal de descubrir y conquistar el mundo, un

${ }^{60}$ G.K. Chesterton, op. cit., p. 53 y ss.

${ }^{61}$ Ibid., p. 41.

62 Ibid., p. 39. 
factor muy importante es el de la identidad. La persona adquiere progresivamente durante la infancia y la adolescencia, conciencia de ser "sí mismo», de su identidad ${ }^{63}$.

Es la familia la que proporciona a cada uno su perfil genético, tanto biológico como psíquico (temperamento, inclinaciones, aptitudes, urdimbre afectiva, costumbres, gestos, modos de ser y reaccionar, conductas, cultura práctica, etcétera). Comunica, además, los valores que más profunda y permanentemente quedan grabados en el espíritu de sus miembros (preferencias, rechazos, actitudes religiosas, virtudes propias, modos de valorar, ideales, etcétera) ${ }^{64}$. Y nos signa con un nombre que contiene todo nuestro yo: actual y potencial.

También cada familia posee su identidad: identidad familiar, que es fundamento directo de la identidad de cada uno y fundamento indirecto de la identidad de la sociedad. De ahí que respetar y defender la propia identidad, es respetar y defender la identidad familiar y la identidad nacional.

Una familia ambigua, inestable, sólo comunica una identidad instantánea, provisional. Pseudoidentidad que se suma, como un número más, a la llamada generación light o equis, determinada por fenómenos superficiales como la moda en el vestir, pensar, opinar, actuar..., todo lo cual interfiere con el desarrollo de un compromiso social, familiar, profesional y moral estable y serio.

Juan Pablo II nos recuerda que: La memoria es la facultad que fragua la identidad de los seres humanos, tanto en lo personal como en lo colectivo. Porque a través de ella se forma y se concretiza en la psique de la persona el sentido de identidad [...] que permite al hombre entenderse a si mismo desde sus más profundas raíces y, al mismo tiempo, en la perspectiva última de su humanidad. Le hace comprender también las últimas comunidades en que se fragua su historia: la familia, la ascendencia y la nación. En fin, le permite adentrarse en la historia de la lengua y de la cultura, en la historia de todo lo que es verdadero, bueno y hermoso ${ }^{65}$.

${ }^{63}$ Cfr. Documentos Pontificios. Familia, matrimonio y uniones de hecho, núm. 8.

${ }^{64}$ Cfr. Ricardo Yepes, Fundamentos de antropología, p. 111.

${ }^{65}$ Juan Pablo II, Memoria e identidad, p. 177 y ss. 


\section{- Lugar de aceptación}

En familia, la persona es aceptada sin condiciones: por lo que es, no por lo que hace. De la aceptación nace el respeto a la persona y sus derechos. Saberse aceptado es la primera lección viva de comprensión, respeto y aceptación de los demás. Esta relación, con el tiempo y bien cuidada, no hace sino aumentar y afirmarse como amor volitivo; amor de benevolencia, profundo y desinteresado. Amor que consiste en procurar el bien del otro y hace que el hogar sea el único sitio en el que un ser humano puede entregarse a otro sin disminución alguna de su persona, su identidad, dignidad o alegría.

En esta dinámica, palabra, gesto y proximidad física, pueden expresar entusiasmo o desprecio, interés o desaliento, alegría o tristeza, aprobación o censura. Amor, respeto y atención, engendran aceptación. Antipatía, agresión e indiferencia, engendran rechazo. La aceptación, ennoblece; el rechazo, envilece. Aceptar es brindar ayuda: tiempo, cooperación, enseñanza o medios que alguien necesita. Es amor en su nítido sentido; amor que colma de alegría. La alegría de estar-con, de vivir-con que hace decir a Borges: Estar o no estar contigo, ésa es la medida de mi tiempo. Porque aceptar, como amar - señala Yepes- es una afirmación alegre: aceptar, aceptarse y ser aceptado es alegrarse. La alegría es el sentimiento que nace de decir: ${ }$ Es bueno que tú existes!» ${ }^{66}$.

Aceptar a los demás comienza por la aceptación de sí mismo, que es mucho más que mera autoestima. Es, quizá, el primer deber que está en la base de todos los demás deberes. Aceptarse es querer ser el que se es y asumir la tarea que nos ha sido asignada; ejercitar la autocrítica, pero con lealtad hacia lo que Dios ha puesto en nosotros. No puedo vivir soñando que soy otro, que hago esto o lo otro, soñando que soy ése o aquel otro ${ }^{67}$. Eso puede ser un ejercicio mental inocente, pero volverse peligroso si se trata de querer evadirse de sí mismo, de lo negativo que descubrimos en nosotros: malas disposiciones, deseos insatisfechos, costumbres consolidadas, culpa acumulada... Debo aceptarlo y hacer frente a ello: así soy, esto he hecho ${ }^{68}$. No con rebeldía; eso no

${ }^{66}$ Cfr. Ricardo Yepes, op. cit., p. 192.

${ }_{67}$ Romano Guardini, La aceptación de sí mismo, p. 20.

${ }^{68}$ Idem. 
es aceptación: es cínico endurecimiento. Sino en verdad, porque sólo la verdad lleva más allá del mal: Soy así, pero quiero llegar a ser de otro modo.

Arrepentirse del mal cometido también es aceptarse. El arrepentimiento es una de las más poderosas formas de expresión de nuestra libertad: en él nos enjuiciamos, poniéndonos contra nosotros mismos del lado del bien y de la justicia. Arrepentirse no es renegar de sí, eso sería desesperación y fuga. Es, más bien, aceptación de lo que hice mal. Este arrepentimiento es una verdad que se convierte en punto de partida de una nueva conducta, de un recomienzo ${ }^{69}$.

\section{- Lugar de la intimidad}

Intimidad es el ámbito interior a cubierto de extraños. Sentimientos, pensamientos o hábitos propios y exclusivos de alguien ${ }^{70}$; lo más idiosincrático, propio y personal, a lo que sólo uno tiene acceso. Cámara interior, íntima, infranqueable, en donde la persona piensa, decide y ama. Individualidad, independencia e intimidad corresponden a la esencia misma de la dignidad personal.

Ahí, cada uno se conoce a sí mismo. Nuestros pensamientos no los conoce nadie, hasta que los expresamos. La interioridad es un mundo interior abierto para mí y oculto para los demás, es intimidad: una apertura hacia dentro. Es el grado máximo de inmanencia, porque no es sólo un lugar donde las cosas quedan guardadas para uno mismo sin que nadie las vea, sino que además es, por así decir, un dentro que crece, del cual brotan realidades inéditas, que no estaban antes: son las cosas que se nos ocurren, planes que ponemos en práctica, invenciones, etcétera. La intimidad tiene capacidad creativa. Por eso, la persona es una intimidad de la que brotan novedades, una intimidad creativa, capaz de crecer $^{71}$.

69 Idem.

${ }^{70}$ Ricardo Yepes, op. cit., p. 75.

${ }^{71}$ Ibid., p. 111. 
De esa intimidad, la persona saca de sí, se manifiesta, se expresa de mil maneras: gesto, palabra, mirada, indumentaria, modales... son distintas formas de expresión ${ }^{72}$. Todas tienen su importancia. Intimidad y expresión indican que la persona es principio y dueña de ambas, y al serlo, es principio y dueña de sí misma y de sus actos. Y es primeramente en la familia en donde nuestra intimidad entra en contacto con la intimidad de los demás mediante el diálogo. Esta intersubjetividad es amistad y constituye la intimidad familiar que hace que el hogar sea el lugar privilegiado de la libertad $y$ de la caridad, en el que uno puede ser de verdad libre, donde mandar es obedecer, reinar es servir y un gozo, sufrir; lugar de amistad, en el que el amigo es más excelso que su mérito, o más bien, amigo y mérito son lo mismo; lugar donde podemos vivir «a gusto» y el sitio donde preferiríamos morir en paz ${ }^{73}$.

\section{- Lugar de realización}

El homo familiaris nace niño en vías de realización; no nace como personalidad plena, ya realizada. Sin familia, el hombre no sería viable, ni siquiera biológicamente. Mucho menos será posible la viabilidad de su realización como persona.

El hombre se realiza en y por la cultura y, por prioridad cronológica, la familia es el primero e insustituible ambiente de realización de todos sus miembros, gracias a su función conservadora y transmisora del patrimonio cultural: es la única manera en que la cultura humana puede permanecer humana. A través del padre y de la madre enlaza el término de patrimonio, concepto que subyace en la palabra «patria» ${ }^{74}$. La pedagogía del liderazgo ha podido comprobar que las virtudes sociales más importantes - la justicia y el amor al prójimo, el genuino sentido de autoridad y obediencia- sólo se forman, ex radice, en el ámbito de la educación y convivencia familiar.

La familia es el primero y más decisivo impulso hacia la realización de cada uno. Del seno familiar, el hombre sale para realizar la propia vocación. La familia es, según vimos, la principal tarea humana, tanto pasiva (la

33 Álvaro de Silva, op. cit., p. 41.

${ }_{74}$ Juan Pablo II, Memoria e identidad, p. 90. 
niñez) como activa (la madurez): en ella se pueden llevar a plenitud las dimensiones humanas más radicales ${ }^{75}$.

Desde su personalísima identidad, todo hombre y toda mujer están llamados a conducir a plenitud, a realizar - hacer real, convertir en realidad - lo recibido como potencialidad, como posibilidad contenida en su ser natural. Es la vocación humana a la plenificación de su ser, a la autorrealización como persona. Ser-yo significa precisamente tener un camino que lleve desde el Yo de la situación inicial al Yo de la plenitud.

En efecto: cada persona se experimenta a sí misma como un bien, pero aún no definitivo, sino más bien como proyecto. Vive no en la satisfacción de lo que ya es, sino en la esperanza de lo que debe llegar a ser y todavía no es. Vive como en tensión hacia una plenitud aún no poseída... [Pero] la tensión hacia la plenitud no es de necesario cumplimiento; depende de la inteligencia y de libertad humanas. Por eso cabe el éxito, pero también cabe el riesgo de la frustración y el fracaso ${ }^{76}$.

\section{GARANTÍA DE UNA SOCIEDAD MÁS JUSTA, LIBRE Y SEGURA}

La familia es la escuela de las virtudes humanas que toda sociedad necesita. La dinámica familiar es la primera educadora de la libertad. Sólo educa el que libera. Sólo libera el que educa. Los miembros de una familia sienten, por así decir, una invitación o inclinación a vivir una biografía común que no es algo ya realizado, sino por realizar solidariamente en un ambiente de seguridad, libertad y justicia. Cada familia, como toda sociedad, es un proyecto que ha de ser vivido, pero que no se cumple necesariamente: depende, como todo desarrollo humano, de la inteligencia y voluntad de los integrantes ${ }^{77}$.

Paternidad, maternidad, filiación, fraternidad, son posiciones sociales determinadas y vinculadas, como a toda posición social, con cargas y expectativas: con su rol social. No todos los individuos están obligados a

75 Ricardo Yepes, op. cit., p. 287.

${ }^{76}$ Cfr. Antonio Ruiz Retegui, Pulchrum, p. 17.

77 Ricardo Yepes, idem. 
formar una familia, pero sí es una obligación de la especie humana que la sociedad debe de facilitar. Los hechos demuestran que existen razones legítimas que explican la formación de familias de lazos espirituales, con frecuencia más fuertes que los lazos de la sangre.

Según vaya la familia, así irá la sociedad. Con la procreación, la libertad llega como un don. La familia, ámbito de encuentro seguro y justo, enseña a pretenderla como conquista y a ejercerla como justicia. Autoridad, estabilidad y vida de relación familiares, constituyen la máxima garantía de libertad, justicia y seguridad sociales. La propia naturaleza exige que la familia sea indisoluble para asegurar la cohesión social. Sólo así podrá seguir siendo la familia: origen de la ciudad y semillero de la república (Cicerón). La ruina de la familia sería el pregón de la ruina social. Ésa sería una crisis que las próximas generaciones resolverían mucho mejor que nosotros, porque ellos habrán pagado primero las consecuencias. Lo ideal sería, desde luego, ahorrarles esa terrible experiencia ${ }^{78}$.

\section{LA ODISEA DEL SIGLO XXI}

Mientras tanto, en muchos ambientes se sigue considerando que la familia es el gran problema; en otros, por fortuna, se considera que es la gran solución. Se insiste en que la familia está en crisis, pero «estar en crisis» no es estar muerto, ni siquiera desahuciado. De la adolescencia se dice - por ejemplo- que es una etapa de crisis, y es preludio de una etapa de mayor consolidación, crecimiento y de vigorosa madurez. Cuando se afirma que un enfermo entró en crisis es, generalmente, el dejar abierta la posibilidad de una franca recuperación. La familia, como institución natural, humana y divina, sigue viva a pesar de los múltiples ataques, internos y externos, teóricos y prácticos, de que es objeto. Porque las cosas muertas pueden ser arrastradas por la corriente; sólo algo vivo, fuerte, dinámico, puede ir contra la corriente.

Alentadas por esta esperanza, son muchas las instancias que postulan el rescate de la familia como la gran odisea del siglo XXI. Recordemos que la

8 Ibid., p. 298. 
Organización de las Naciones Unidas declaró 1994 como el Año Internacional de la Familia, iniciativa que trató de poner de manifiesto que la cuestión familiar es fundamental para los Estados miembros de la ONU. Poco antes, en la fiesta de la Sagrada Familia de 1993, se inauguró en toda la Comunidad eclesial el "Año de la Familia», como etapa significativa en la preparación del Gran Jubileo del año 2000. De este modo, y continuando una tradición de siglos, el Papa Juan Pablo II quiso subrayar la atención prioritaria de este tema a lo largo de su pontificado; atención que ya preludiaba la labor pastoral de su sucesor. Estas iniciativas han contribuido a la difusión y conocimiento de la Declaración Universal de los Derechos Humanos de las Naciones Unidas, y la Carta de los Derechos de la Familia de la Santa Sede.

Huelga decir que el rescate de la familia no consiste sólo en sacarla de la crisis, sino en reivindicarla como valor fundamental y fuente de valores; como idea motriz que dé nueva luz, mayor energía y más claro sentido a la vida; como factor de unidad, solidaridad y alegría entre los hombres en este siglo que apenas comienza. Es una odisea orientada a desvelar su vigencia y centralidad; reconocer su papel en el progreso del país; destacar su función en el desarrollo profesional y ético-social de hombres y mujeres; enfatizar su función pedagógico-cultural en los jóvenes; y reivindicar sus fecundas posibilidades en las nuevas políticas socio-laborales.

Atendiendo a tal propósito, este trabajo pretende subrayar la necesidad de reexaminar nuestro criterio acerca de la institución familiar: su naturaleza, estructura, misión y sentido. En el entendido de que el tema de la familia es inagotable y no se estudia sólo a través de los sentidos, que únicamente captan la evidencia accidental, sino a través de una visión más penetrante que supere las apariencias sensibles.

Según señalamos, el lema de esta odisea no debe ser ¡Familia: vuelve a ser lo que eras!, sino ¡Familia: llega a ser lo que eres, lo que debes ser!: primera escuela de amor, unión y libertad; lugar privilegiado de intimidad e identidad, de aceptación y realización personal; mejor garantía de una sociedad más justa, más libre y más segura. Si vemos hacia el pasado, es sólo para rescatar lo esencial en pro del futuro. 
Es preciso insistir acerca del papel activo que, en este rescate, deben asumir las familias mismas. Deben ser: las primeras en procurar que las leyes no sólo no ofendan, sino que sostengan y defiendan positivamente los derechos y deberes de la familia ${ }^{79}$, promoviendo así una verdadera «política familiar» ${ }^{80}$.

\section{... NI PACÍFICA, NI CÓMODA, NI UNIDA}

Por lo demás, es justo decir siempre la verdad: la familia no siempre es pacífica, ni cómoda, ni unida. Es, sí, el lugar de las mayores alegrías, pero también de los mayores pesares. Cada persona, cada aspecto, cada momento de la vida familiar es impredecible, es un problema actual o potencial: nunca se sabe lo que va a pasar. ¡Eso es lo que la hace tan apasionante! Quizá unos cuantos poderosos todo lo puedan prever y controlar, ¡por eso se aburren! Pero para el común de los mortales: La aventura suprema es nacer... Ahí nos encontramos de repente en una trampa espléndida y estremecedora. Al entrar en la familia por el nacimiento entramos en un mundo incalculable, en un mundo que tiene sus leyes propias y extrañas, en un mundo que podría muy bien continuar sin nosotros; en un mundo que no hemos fabricado nosotros... Ahí vemos de verdad algo que jamás habiamos soñado antes. Nuestro padre y nuestra madre están al acecho, esperándonos, y saltan sobre nosotros como si fueran bandoleros detrás de un matorral. Nuestro tío es una sorpresa. Nuestra tía es como un relámpago en un cielo azul. Y ese carácter extraño de la vida familiar, este ingrediente inesperado y hasta perverso de las cosas tal como acontecen, permanece incurablemente interesante ${ }^{81}$. Por eso nacer, crecer, fundar y cuidar una familia puede ser, si queremos, la aventura humana y sobrenatural más apasionante, fecunda y divertida de nuestro proyecto vital. Y aquello de: Honrarás a tu padre y a tu madre; y que el hermano, ayudado por su hermano es como una ciudad firmemente defendida; y que un amigo es una fuerte protección, pueden seguir siendo de nuestras verdades más consoladoras.

En suma, este rescate de la familia puede ayudar a renovar la faz de la tierra. Nuestra sociedad y nuestra cultura necesitan renovarse. La sociedad

Cfr. Familiaris consortio, núm. 44.

${ }^{80}$ Cfr. Francisco Fernández Carvajal, Hablar con Dios, t. III, p. 477.

${ }^{81}$ G.K. Chesterton, op. cit., p. 45. 
y la cultura no sólo se conservan: evolucionan, progresan, ésa es su ley. Únicamente que a la palabra «progreso» se la ha dotado de una aureola casi mágica. [...] Progreso solo puede ser un concepto razonable si sabemos hacia dónde queremos ir; el mero movimiento sin más, no supone ningún progreso [...]. Para que sea progreso tiene que preguntarse cuál es su escala de referencia y cuál es su meta ${ }^{82}$.

La odisea del siglo XXI debe interesar a jóvenes y a adultos, a la sociedad entera. Importan, para el rescate de la familia, tanto la ponderada experiencia de unos como el ímpetu innovador de otros. Sin esta colaboración se corre el peligro de obstaculizar el auténtico progreso, ya sea por una obstinada veteromanía (manía por lo pasado) paralizante, o por una irresponsable y desarticulante neomanía (manía por lo novedoso). Toda colaboración - lo sabemos- sólo puede darse entre unidades, no entre ceros. Y sabemos también que: Aquel que quiera cambiar el mundo, debe empezar por cambiarse a sí mismo (Sócrates). El rescate de la institución familiar comienza por el rescate de la propia familia.

Como institución basada en la comunidad de origen natural y depósito de los valores más profundos del espíritu humano, la familia no es un asunto meramente político. Es, sobre todo, moral y religioso. Ya el cristianismo, por enorme que fuera la revolución que supuso, no alteró esta cosa sagrada, tan antigua y salvaje; no hizo nada más que darle la vuelta. No negó la trinidad padre, madre y niño. Sencillamente lo leyó al revés, haciéndola niño, madre y padre. Y ésta ya no se llama familia, sino Sagrada Familia, pues muchas cosas se hacen santas sólo con darles la vuelta ${ }^{83}$.

\section{GUÍA DE REFLEXIÓN}

En nuestro trabajo con numerosos grupos, hemos podido elaborar, conjuntamente, la siguiente tabla comparativa entre lo que «suelen hacer» y lo que la experiencia común aconseja que «deben hacer» el padre o la madre de familia. Creemos que, aunque breve, puede servir como guía para la reflexión y el diálogo:

${ }^{82}$ Joseph Ratzinger, op. cit., p. 125.

${ }^{83}$ G.K. Chesterton, op. cit., p. 58. 
SUELE HACER:

DEBE HACER:

\begin{tabular}{|c|c|}
\hline $\begin{array}{l}\text { Muestra, con su conducta, que sus asuntos y } \\
\text { relaciones importantes están fuera del hogar: } \\
\text { socios, negocios, reuniones, viajes... }\end{array}$ & $\begin{array}{l}\text { "Dejar que se note" la importancia que le } \\
\text { merecen los asuntos familiares, aunque } \\
\text { tenga que "verse forzado" a atender otras } \\
\text { responsabilidades. }\end{array}$ \\
\hline $\begin{array}{l}\text { Externa demasiado francamente sus que- } \\
\text { jas de la familia: indisciplina, desorden, } \\
\text { ruido, desobediencias... }\end{array}$ & $\begin{array}{l}\text { Nunca proyectar una visión negativa de la } \\
\text { problemática familiar. Recordar que: la pre- } \\
\text { tensión de una familia perfecta, es un } \\
\text { sueño que puede convertirse en una pesa- } \\
\text { dilla, o peor, en una maldición. }\end{array}$ \\
\hline Se fija únicamente en los defectos. & $\begin{array}{l}\text { Ver también lo positivo. Saber hacer agra- } \\
\text { dables y atrayentes el valor y la virtud. Ver, } \\
\text { con lupa, lo positivo. }\end{array}$ \\
\hline $\begin{array}{l}\text { Confunde educación con escolaridad, y } \\
\text { formación con enseñanza. }\end{array}$ & $\begin{array}{l}\text { La educación de los hijos es responsabili- } \\
\text { dad de los padres. Se delegan funciones, } \\
\text { pero no responsabilidades. No sólo "ense- } \\
\text { ñar" los valores, sino "formar" en virtudes. } \\
\text { El valor es el bien pensado, la virtud es el } \\
\text { bien vivido. }\end{array}$ \\
\hline $\begin{array}{l}\text { Cede fácilmente a las ideas, usos y cos- } \\
\text { tumbres de moda, con el peligro de acep- } \\
\text { tar como normal y bueno, lo que no lo es. }\end{array}$ & $\begin{array}{l}\text { A veces ir contra la corriente: no acostum- } \\
\text { brarse al mal, ni pactar con la mediocridad. } \\
\text { Sólo lucha contra corriente un ser vivo, } \\
\text { dinámico; una cosa inerte } 0 \text { un cadáver, se } \\
\text { dejan arrastrar. }\end{array}$ \\
\hline $\begin{array}{l}\text { Se esmera, como líder exitoso que es, en } \\
\text { suscitar el reconocimiento y la admiración } \\
\text { del cónyuge y de los hijos. }\end{array}$ & $\begin{array}{l}\text { Recordar que el líder que se conforma con } \\
\text { ser admirado, ha fracasado, se ha quedado } \\
\text { a medias. Debe tratar de ser digno de ser } \\
\text { imitado. El verdadero éxito se construye con } \\
\text { humildad, buen prestigio y buen ejemplo. }\end{array}$ \\
\hline $\begin{array}{l}\text { Su autoridad se polariza entre la "frialdad } \\
\text { de la lógica" y el "calor de la pasión». }\end{array}$ & $\begin{array}{l}\text { Recordar el valor de la templanza. La auto- } \\
\text { ridad no debe ser: ni tan fría que pierda el } \\
\text { calor del sentimiento, ni tan caliente, que } \\
\text { pierda la dignidad de la idea: debe ser } \\
\text { "refrigerada", templada. }\end{array}$ \\
\hline
\end{tabular}


SUELE HACER:

DEBE HACER:

Quiere, con buena voluntad, evitar todo conflicto entre su liderazgo familiar y su liderazgo social.
Tener presente que el conflicto suele darse, no por falta de voluntad, sino por falta de criterio. Ciencia, competencia y experiencia no caen como ciencia infusa. Hay que dedicar tiempo a la propia formación.

\section{BIBLIOGRAFÍA}

- ALTAREJOS F. et al., Lo permanente y lo cambiante en la educación, EUNSA, Pamplona, 1991.

- ARÉCHEGA Ignacio, «Encuentro mundial de las familias», Aceprensa [en línea, disponible sólo para suscriptores]: [http:/ / www.aceprensa.com/]. Consultado: 06-VII-2006. ISSN: 1135-6936.

- AYLLON, José Ramón, Luces en la caverna, Ed. Martínez Roca, Barcelona, 2001.

- BENNER, Dietrich, La pedagogía como ciencia, Ed. Pomares, Barcelona, 1998.

- BOWEN-HOBSON, Teorías de la educación, Limusa, México, 1995.

- CHARMOT, François, Esbozo de una pedagogía familiar, Herder, Barcelona, 1964.

- CHESTERTON, G.K., El amor o la fuerza del sino, Rialp, Madrid, 1995.

- CHESTERTON, G.K., Hombrevida, Continental, México, s/d. 
- CLARK, Kim B., Liderazgo, valores y educación en un mundo atribulado, Discurso pronunciado durante el acto académico de investidura de grado de doctor Honoris Causa, Instituto Panamericano de Alta Dirección de Empresa (IPADE), Ciudad de México, febrero 2005.

- DISCURSOS. Universidad Panamericana/ Instituto Panamericano de Alta Dirección de Empresa, México, 2005.

- DOCUMENTOS PONTIFICIOS: Carta a las familias; Familiaris Consortio; Familia, matrimonio y uniones de hecho.

- FERNÁNDEZ, Bernardo, Ética de la dirección, Granica, México, 2000.

- FERNÁNDEZ C., Francisco, Hablar con Dios, t. III, Ed. Palabra, Madrid, 1998.

- GRAMSCI, Antonio, La alternativa pedagógica, Fontamara, México, 1998.

- GUARDINI, Romano, La aceptación de sí mismo. Las edades de la vida, Ed. Cristiandad, Madrid, 1977.

- HERMOSO E., Paciano, Teoría de la educación, Trillas, México, 1994.

- INAYATULLAH, Sohail y GIDLEY, Jennifer, La universidad en transformación, Pomares, Barcelona-México, 2003.

- JUAN PABLO II, Memoria e identidad, Editorial La Esfera de los Libros, Madrid, 2005.

- LERMA J., Héctor, Paternidad: excelencia o fracaso, México, Minos, 1998.

- LUCIANI, Albino, Ilustrísimos señores, Rialp, Madrid, 1978.

- LLANO, Alejandro, Gnoseología, EUNSA, Pamplona, 1984.

- MATA, Santiago y MONTÓN, Carmen, «La auténtica "política social" del siglo XXI: Conciliar familia y trabajo, sin malabarismos», Aceprensa [en línea, disponible sólo para suscriptores]:

[http: / / www.aceprensa.com/]. Consultado: 02-II-2005. ISSN: 1135-6936.

- MATA, Santiago, «Conciliar familia y trabajo sin malabarismos: La clave es la flexibilidad de las empresas», Aceprensa, núm. 10/05 [en línea, disponible sólo para suscriptores]:

[http:/ / www.aceprensa.com/]. Consultado: 2-II-05. ISSN: 1135-6936.

- MELENDO, Tomás, «La familia en la Universidad», Istmo, núm. 279, julio-agosto, México, 2005. 
- NAVARRO, Ana Ma., «Papel de la familia en el futuro», Lo permanente y lo cambiante en la educación, EUNSA, Pamplona, 1991.

- PADILLA, M.R., Héroes mitológicos, EDIMAT, Madrid, 2002.

- PAUlO VI, Populorum Progressio.

- PÉREZ LÓPEZ, J.A., Liderazgo, IESE, Barcelona, 1997.

- PIEPER, Josef, El ocio y la vida intelectual, Rialp, Madrid, 1979.

- RATZINGER, Joseph, Dios y el mundo, Mondadori, Barcelona, 2005.

- RODRÍGUEZ LUÑO, Ángel, Ética, EUNSA, Pamplona, 1984.

- RUIZ RETEGUI, Antonio, Pulchrum, Editorial Rial, Madrid, 1998.

- SECO, Luis Ignacio, Chesterton, Palabra, Madrid, 1998.

- SPEAMANN, Robert, Ética: Cuestiones fundamentales, EUNSA, Pamplona, 2005.

- YEPES, Ricardo, Fundamentos de antropología, EUNSA, Barañáin, 1997. 
